\title{
SOME RESULTS AND CONCLUSIONS OF THE RESEARCH OF TEACHING APPLIED MATHEMATICS EFFICIENCY BY MS EXCEL
}

\author{
Jana BORŽÍKOVÁ
}

\begin{abstract}
The paper deals with quantitative and qualitative analysis of the research of efficiency Applied Mathematics teaching at Faculty of Manufacturing Technologies TUKE with seat in Prešov by using MS Excel. The article introduces using methods, analyses four tested hypothesis and presented obtained results.
\end{abstract}

Key words: numerical methods, subject an Applied Mathematics, research, control group, experimental group.

\section{VÝSLEDKY A ZÁVERY VÝSKUMU EFEKTÍVNOSTI VYUČOVANIA APLIKOVANEJ MATEMATIKY POMOCOU MS EXCEL}

Resumé: Príspevok sa zaoberá kvantitativnym a kvalitatívnym rozborom výskumu efektívnosti vyučovania aplikovanej matematiky na Fakulte výrobných technológii TUKE so sídlom v Prešove s využitím MS Excel. Cllánok uvádza použité metódy, analyzuje štyri testované hypotézy a prezentuje ziskané výsledky.

Kličová slova: numerické metódy, predmet Aplikovaná matematika, výskum, kontrolná skupina, experimentálna skupina.

\section{1 Úvod}

Technický rozvoj a množstvo informácií, ktoré nás denne zaplavujú nás núti zamysliet' sa nad tým, čo má zmysel robit' tak, ako to bolo zvykom. Hlavne na vysokých školách technického zamerania tlak zo strany technických predmetov vyvoláva zmeny aj $\mathrm{v}$ študijných programoch príbuzných predmetov. Počet hodín vyčlenených na tieto predmety klesá, klesá aj úroveň vedomostí, ktoré prinášajú študenti zo stredných škôl. Jednou z možností riešenia je zmena organizácie výučby. [1]

$\mathrm{Z}$ uvedeného vidíme, že, na väčšine fakúlt dochádza k zmene organizácie prednášok a cvičení, k zvyšovaniu snahy podporovat' prípravu inžiniera pomocou „vhodnej“ výpočtovej techniky. Vzniká otázka, ktorý $z$ dostupných softvérov použit' pri vyučovaní matematiky, konkrétne aplikovanej matematiky.

Ak zvážime doteraz spomenuté kritériá: pripravenost' študentov $\mathrm{z}$ matematiky, ich počítačovú gramotnost', možnosti a potreby predmetu a finančnú dostupnost' na trhu, budeme sa z programov MS Excel, Matlab, Mathematica, programovací jazyk Pascal (Delphi) bližšie venovat' aplikácii MS Excelu na hodinách aplikovanej matematiky. Ide o tabul'kový procesor využívajúci všetky výhody práce s dátami, tabul'kami. Umožňuje tieto dáta d’alej spracovávat' numericky aj graficky. Cez absolútne a relatívne odkazy pracuje so vzorcami.

Vel'kou výhodou využitia MS Excel pri vyučovaní numerickej matematiky je jeho dostupnost' na trhu a pripravenost' študentov. Posledné ročníky študentov $\mathrm{v}$ rámci stredoškolských učebných osnov absolvovali už celý balík programov Microsoft (MS Word a MS Excel, ...). Aj ked' nie je priamo určený pre riešenie numerických úloh, má pre to predpoklady a obsahuje niektoré doplnky (napr. Solver, Analýza dát), ktoré pomôžu pri riešení takýchto úloh. Podobne niektoré funkcie (napríklad Linregrese a Lintrend) umožňujú riešit' uvedené úlohy.

$\mathrm{V}$ predmete je iba nástrojom, nie ciel'om. Je vhodný pre začiatočníkov a súčasne spolu s Visual Basic umožní aj „lepším“ študentom zvyšovat' svoje zručnosti a využit' kreativitu.

Vhodnost' využitia MS Excelu ako didaktickej pomôcky na hodinách aplikovanej matematiky bola d'alej overovaná porovnaním dosiahnutých výsledkov v dvoch rôznych ročníkoch. A tomu sa venoval prezentovaný výskum.

\section{Ciel' výskumu a stanovené hypotézy}

Z obsahu predchádzajúcej kapitoly bol konkretizovaný nasledujúci ciel' výskumu: 
Zvýšenie efektívnosti vyučovania aplikovanej matematiky pomocou MS Excel.

V závislosti od stanoveného ciel'a bola formulovaná východisková hypotéza:

H: Využlvanie MS Excelu na hodinách aplikovanej matematiky v podmienkach našej fakulty je efektívnejšie.

Pre sledovanie kvality využívania MS Excelu vo vyučovacom procese sa ako najvhodnejší javil výskum Ex post facto. Mnohé problémy v pedagogike je t’ažké, ba niekedy nemožné overit' experimentálne. Téma je časovo náročná, t. j. kvalita softvéru sa mení každou minútou. Každoročne prichádzajú na trh nové programy, ktoré sú využitel'né v aplikovanej matematike. Ďalej je téma ovplyvnitel'ná aj inými objektívnymi faktormi. V čase výskumu prichádzali na kurzy aplikovanej matematiky pomerne slabí študenti z prechodových ročníkov a na fakulte sa znižoval počet hodín matematiky, čo ovplyvnilo kvalitu výučby.

Výskum ex post facto môže flexibilnejšie reagovat' na aktuálne potreby pedagogickej praxe. Ak je správne určená príčina sledovaných javov, aktuálne navrhnutá zmena prinesie zlepšenie vyučovacieho procesu a je možné ju hned' zaradit' do vyučovacieho procesu. Minimalizuje sa vplyv skúmaného prvku (edukanta), pretože ten nevie, že je súčast’ou výskumu. Študenti na vysokých školách si sú vedomí toho, že čast' úspechu môžu dosiahnut' aj tým, že zist'ujú informácie o predmete aj z iných zdrojov (napríklad iných študijných skupín a u iných cvičiacich). Tým by nastal prienik medzi informáciami $\mathrm{z}$ experimentálnej a kontrolnej skupiny pri empirickom výskume. Mohol by nastat' tiež Hawthornský efekt [2], ktorý hovorí, že l'udia vybraní do výskumu sa môžu cítit' poctení a snažia sa tak dosiahnut' vyššie výsledky.

Všeobecnou nevýhodou výskumu ex post facto je nesprávne vytvorený záver. Aby sme sa vyhli tomuto riziku, vyberieme takú skupinu, vktorej môžeme minimalizovat' počet premenných faktorov. Ako d'alšiu nevýhodu tohto výskumu by som uviedla to, že zovšeobecnenie nastáva iba na malej vzorke, napríklad bude to zovšeobecnenie platné na domácej fakulte.

Pracovné hypotézy boli formulované nasledovne:

- H1: MS Excel prispieva k lepšiemu pochopeniu a zapamätaniu danej metódy, čo sa prejaví na vyššom hodnotení študentov na skúške.
- H2: Študenti získavajú vyšie bodové hodnotenie pri jednotlivých úlohách pri používaní MS Excelu.

- H3: MS Excel zabezpečuje komplexné (úplné) riešenie úlohy, čo sa prejaví vyšším percentom úplne vyriešených úloh.

- H4: Využívanie MS Excelu znižuje percento numerických chýb v porovnaní s Pascalom.

\section{Kvantitatívne zhodnotenie výsledkov \\ hypotézy 1}

Boli vykonané nasledujúce šetrenia:

- tabul'kou absolútnych a kumulatívnych početností a grafom sú vyhodnotené výsledky študentov pri udel'ovaní zápočtov v skupine A,

- tabul'kou absolútnych a kumulatívnych početností a grafom sú vyhodnotené výsledky študentov pri skúške v skupine A,

- tabul'kou absolútnych a kumulatívnych početností a grafom sú vyhodnotené výsledky študentov pri udel'ovaní zápočtov v skupine B,

- tabul'kou absolútnych a kumulatívnych početností a grafom sú vyhodnotené výsledky študentov pri skúške v skupine $B$,

- párovým testom sa potvrdzovala rovnost' výsledkov na zápočte a skúške $\mathrm{v}$ skupine $\mathrm{B}$,

- Wilcoxonovým testom sa potvrdzovala rovnost' výsledkov na zápočte a skúške $\mathrm{v}$ skupine B.

Uvediem získané výsledky:

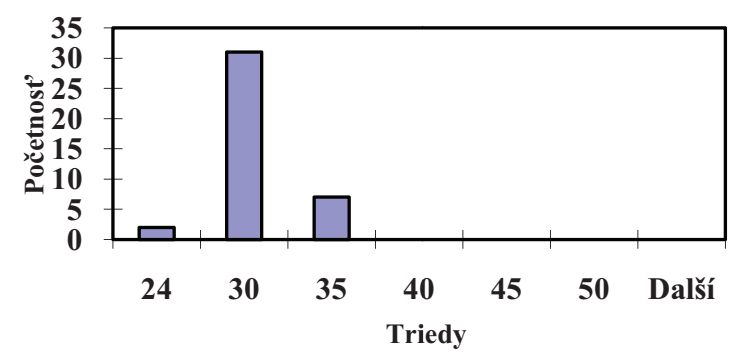

Obr 1: Početnosti študentov na zápočte v skupine A

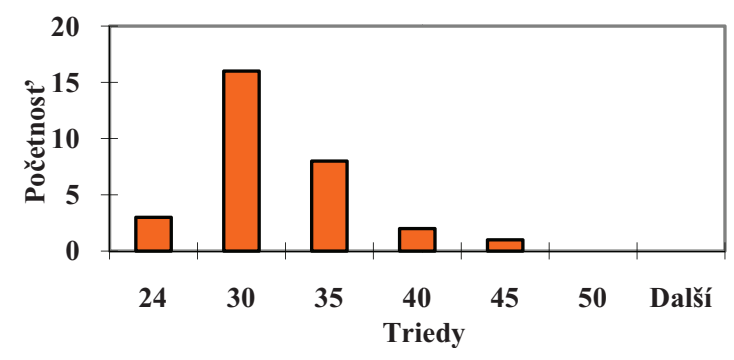

Obr 2: Početnosti výsledkov študentov na skúške $v$ skupine A 


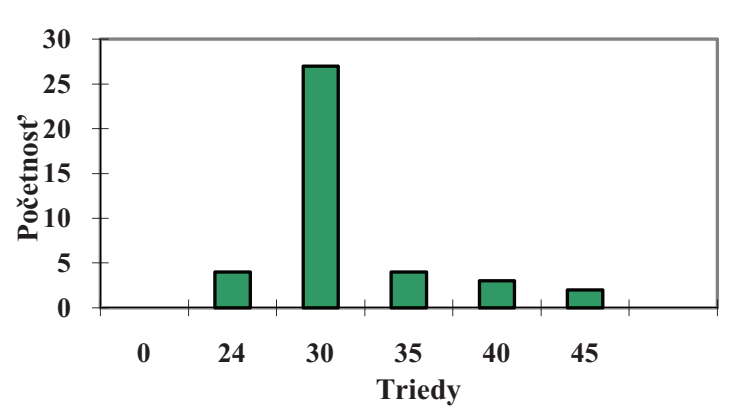

Obr 3: Početnosti výsledkov pri udelovaní zápočtu v skupine $B$

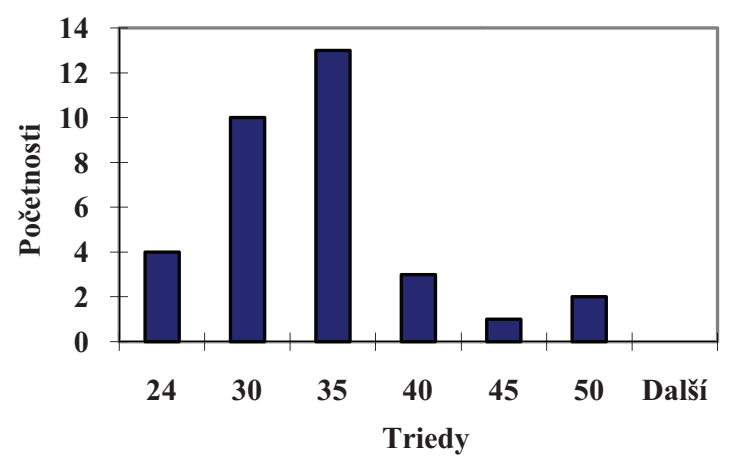

Obr 4: Početnosti výsledkov na skúške v skupine $B$

Ďalej uvediem výsledky párového testu na potvrdenie rovnosti výsledkov na zápočte a skúške v skupine B. Overovali sme vplyv rôznej metodiky vyučovania na výsledky študentov na skúške. Na overenie rovnosti štatistických výberov bol použitý párový test [3]. So súboru boli vylúčení študenti, ktorým nebol udelený zápočet (4), alebo sa nedostavili na skúšku ani $\mathrm{v}$ jednom termíne (3).

Nech $\left(\eta_{1}, \eta_{2}\right)$ je vektor stredných hodnôt. Testovali sme hypotézu

$H_{0}:\left(\eta_{2}-\eta_{1}\right)=\Delta=0$ proti $H_{1}:\left(\eta_{2}-\eta_{1}\right)=\Delta \neq 0$.

Testovacia štatistika je veličina

$|t|=\frac{\bar{Z}}{S} \sqrt{n}=7,86$

ktorá ma t-rozdelenie. Hodnota $\bar{Z}$ je aritmetický priemer rozdielov a $\mathrm{S}$ je ich smerodajná odchýlka. Hypotézu zamietame, pretože $|t|>2,7$.

Pričom 2,7 je hodnota pre t-rozdelenie na hladine významnosti $\alpha=0,02: t(0,01,32)$.

Wilcoxonov test na potvrdenie rovnosti výsledkov na zápočte a skúške v skupine B. [3] So súboru boli vylúčení študenti, ktorým nebol udelený zápočet (4), alebo sa nedostavili na skúšku (3). Vypočítali sme rozdiely $\mathrm{Zi}$ dosiahnutých výsledkov u jednotlivých študentov. Súčty poradí kladných rozdielov a záporných rozdielov sú.

$$
\begin{aligned}
& \mathrm{R}^{+}=332 \\
& \mathrm{R}^{-}=229
\end{aligned}
$$

$\operatorname{Min}(229,332)=229>138$

(138 je kritická hodnota $\mathrm{z}$ tabuliek na hladine významnosti 0,01 pre $n=33$ ).

Nebolo splnené kritérium a teda hypotézu o rovnosti nezamietame.

\section{Kvantitatívne zhodnotenie výsledkov hypotézy 2}

Pri každej riešenej úlohe $\mathrm{v}$ teste je vykonaná analýza dosiahnutých výsledkov, absolútne a relatívne početnosti jednotlivých bodových hodnotení. Dvojvýberovým Wilcoxonovým testom je overená rovnost' (rôznost') hodnotenia.

Pre nedostatok miesta uvediem, len príklady pre výskum zaujímavých výsledkov.

Riešenie úloh pomocou metódy najmenších štvorcov [4]:

V oboch skupinách A aj B bola cvičená lineárna, hyperbolická, kvadratická aj kubická závislost'. Všetky tieto typy sa vyskytovali aj $\mathrm{v}$ testových úlohách. V prípade formulácie jednoduchšej úlohy bolo potrebné spracovat' dve závislosti a vzájomne ich porovnat'. $100 \%$ zvládnutá úloha bola hodnotená 4 bodmi.

V skupine A bola úloha riešená 39 študentmi. Aritmetický priemer je 2,97, smerodajná odchýlka 1,07 , rozptyl 1,53. V skupine B bola táto úloha riešená 39 študentmi s celkovým bodovým hodnotením 4 body. Aritmetický priemer bodov $\mathrm{v}$ tejto skupine bol 3,29, smerodajná odchýlka 1,13, rozptyl 1,29. (Obr. 5)

Hypotézu o rovnosti distribučných funkcií výberov skupiny A a skupiny $\mathrm{B}$ overíme dvojvýberovým Wilcoxonovým testom. Testujeme teda: $H_{0}:\left(F_{1}(x)=F_{2}(x)\right)$ proti $H_{1}:\left(F_{1}(x) \neq F_{2}(x)\right)$ Usporiadame $n=78$ hodnôt podla vel'kosti a priradíme im poradie $X_{11}, \ldots X_{1 n_{1}}$ a $X_{21}, \ldots X_{2 n_{2}}$ . Určíme štatistiky

$S_{1}=n_{1} n_{2}+\frac{n_{1}\left(n_{1}+1\right)}{2}-T_{1}=981 \mathrm{a}$

$S_{2}=n_{1} n_{2}+\frac{n_{2}\left(n_{2}+1\right)}{2}-T_{2}=535,5$. pričom

$T_{1}=X_{11}+X_{12}+\ldots+X_{1 n_{1}}=1320 \mathrm{a}$

$T_{2}=X_{21}+X_{22}+\ldots+X_{2 n_{2}}=1765,5$.

Ked'že $n$ je dostatočne vel'ké, určíme veličinu 
$U=\frac{S_{1}-\frac{n_{1} n_{2}}{2}}{\sqrt{\frac{n_{1} n_{2}}{12}\left(n_{1}+n_{2}+1\right)}}=-2,248$

Keďže platí, že $|U| \geq 2,170, \quad u\left(\frac{\alpha}{2}\right)=2,170$, hypotézu na hladine významnosti 0,03 zamietame, teda je významný rozdiel medzi výberom $A$ a $B$.
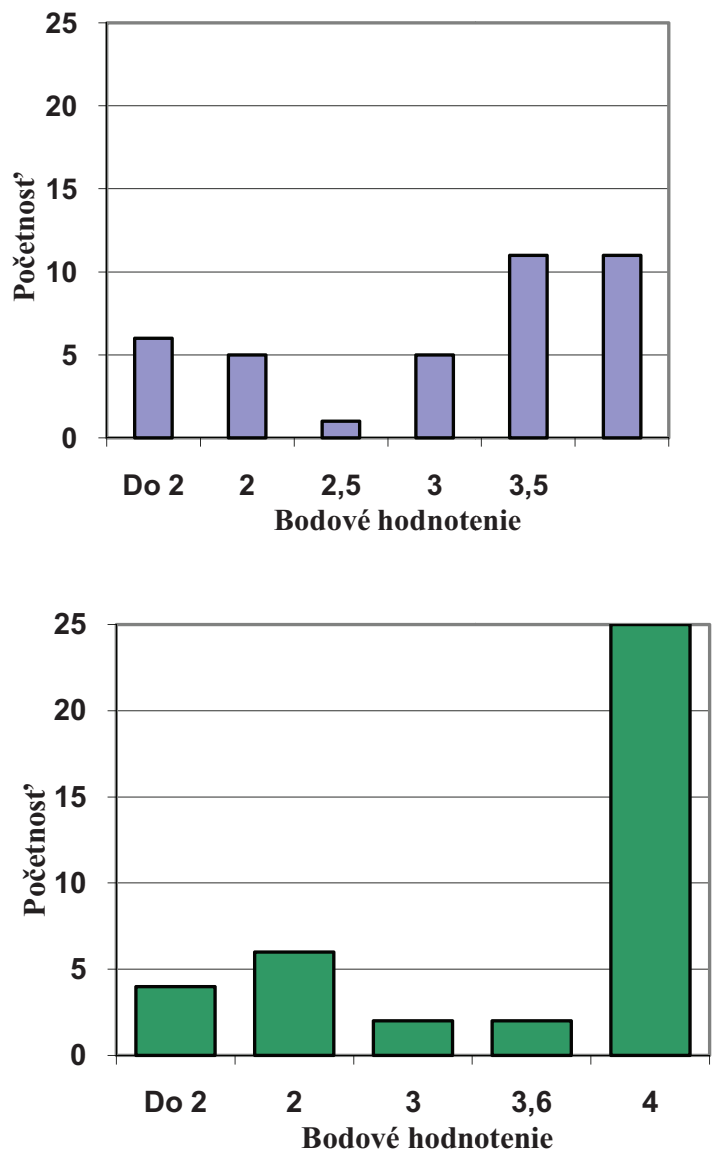

Obr 5: Grafické porovnanie výsledkov a skupine A a v skupine B

\section{Riešenie nelineárnej rovnice:}

Ďalšie úlohy $\mathrm{v}$ oboch kontrolných prácach boli zamerané na riešenie jednej nelineárnej rovnice. Ked’že z výsledkov bolo jasné, že študenti majú problém so zvládnutím týchto typov, tak s odstupom ročníkov sa zmenila skladba písomných prác. V skupine $\mathrm{B}$ sa vyskytovali 3 úlohy z tejto oblasti, pričom jedna bola zameraná iba na separáciu koreňov. V skupine A, boli obe s plným počtom bodov 3 a boli riešené 40 študentmi.

Dosiahnutý aritmetický priemer pri jednotlivých testových úlohách bol 0,875 a 0,8 , smerodajná odchýlka 1,06 a 1,03, rozptyl 1,13 a 1,07. Prvú aj druhú úlohu na riešenie jednej nelineárnej rovnice riešilo 38 študentov. Maximálny možný počet bodov za každú úlohu bol 4 body.
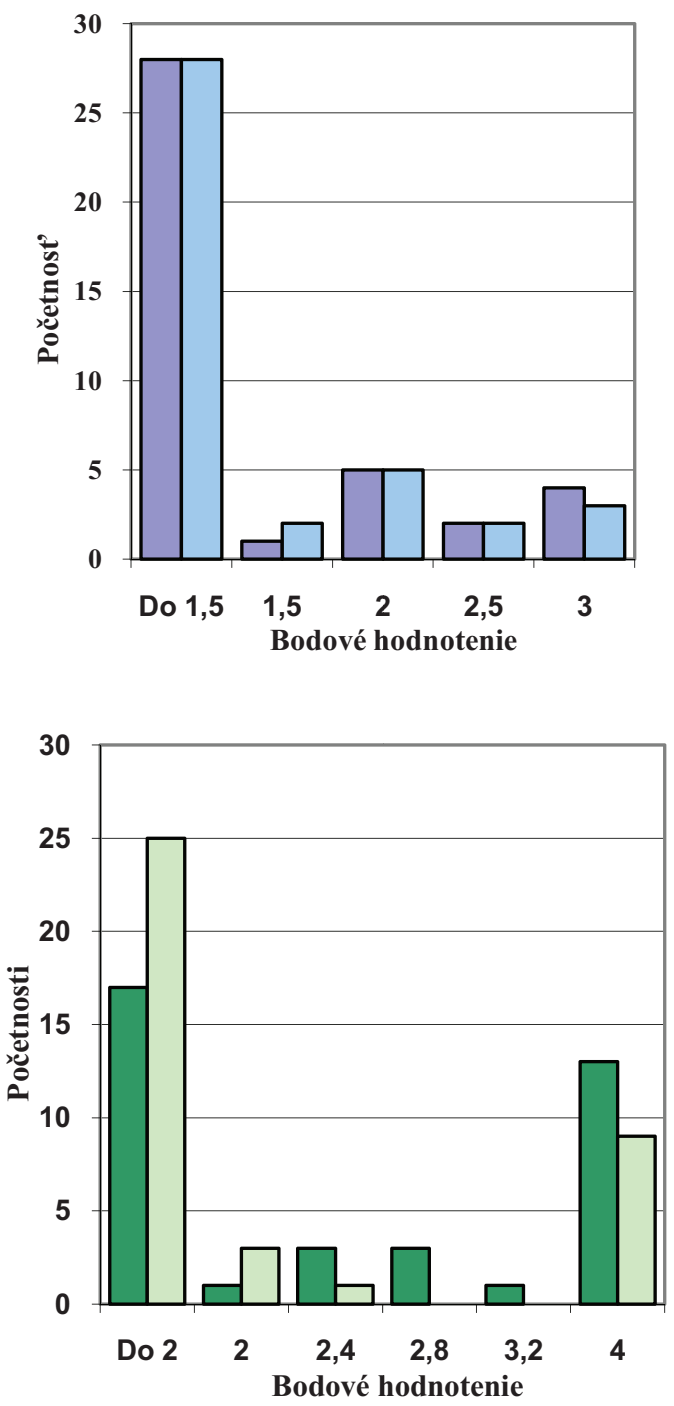

Obr 6: Porovnanie bodového hodnotenia $v$ skupine A a v skupine B

Hypotézu o rovnosti distribučných funkcií výberov skupiny A a skupiny $\mathrm{B}$ overíme dvojvýberovým Wilcoxonovým testom. Overovat' budeme osobitne obe úlohy.

Testujeme prvú úlohu:

$H_{0}:\left(F_{1}(x)=F_{2}(x)\right)$ proti $H_{1}:\left(F_{1}(x) \neq F_{2}(x)\right)$

Usporiadame $\mathrm{n}=78$ hodnôt podl'a vel'kosti a priradíme im poradie $X_{11}, \ldots X_{1 n_{1}}$ a $X_{21}, \ldots X_{2 n_{2}}$. Určíme štatistiky

$S_{1}=n_{1} n_{2}+\frac{n_{1}\left(n_{1}+1\right)}{2}-T_{1}=1017 \mathrm{a}$ 
$S_{2}=n_{1} n_{2}+\frac{n_{2}\left(n_{2}+1\right)}{2}-T_{2}=499$. pričom

$T_{1}=X_{11}+X_{12}+\ldots+X_{1 n_{1}}=1323 \mathrm{a}$

$T_{2}=X_{21}+X_{22}+\ldots+X_{2 n_{2}}=1762$.

Ked'že $n$ je dostatočne vel'ké, definujeme veličinu

$U=\frac{S_{1}-\frac{n_{1} n_{2}}{2}}{\sqrt{\frac{n_{1} n_{2}}{12}\left(n_{1}+n_{2}+1\right)}}=2,61$

Ked’že $|U| \geq 2,576, u\left(\frac{\alpha}{2}\right)=2,576$, hypotézu na hladine významnosti 0,01 zamietame.

Testujeme druhú úlohu:

$H_{0}:\left(F_{1}(x)=F_{2}(x)\right)$ proti $H_{1}:\left(F_{1}(x) \neq F_{2}(x)\right)$

Usporiadame $n=78$ hodnôt podla vel'kosti a priradíme im poradie $X_{11}, \ldots X_{1 n_{1}}$ a $X_{21}, \ldots X_{2 n_{2}}$. Určíme štatistiky

$S_{1}=n_{1} n_{2}+\frac{n_{1}\left(n_{1}+1\right)}{2}-T_{1}=1389,5 \mathrm{a}$

$S_{2}=n_{1} n_{2}+\frac{n_{2}\left(n_{2}+1\right)}{2}-T_{2}=1637,5$. pričom

$T_{1}=X_{11}+X_{12}+\ldots+X_{1 n_{1}}=950,5 \mathrm{a}$

$T_{2}=X_{21}+X_{22}+\ldots+X_{2 n_{2}}=623,5$.

Ked'že $n$ je dostatočne vel'ké, určíme veličinu

$U=\frac{S_{1}-\frac{n_{1} n_{2}}{2}}{\sqrt{\frac{n_{1} n_{2}}{12}\left(n_{1}+n_{2}+1\right)}}=1,90$

Ked'že $|U| \geq 1,695, u\left(\frac{\alpha}{2}\right)=1,695$, hypotézu zamietame, ale až na hladine významnosti 0,06.

\section{Numerické riešenie diferenciálnej rovnice:}

Najčastejšie vyskytujúce sa úlohy $\mathrm{z}$ tejto problematiky $\mathrm{v}$ kontrolných testoch boli riešenia diferenciálnych rovníc pomocou Eulerovej metódy a Runge-kutta 2. a 4. rádu.

Celkový počet bodov bol 4 body v skupine A aj $B$. V skupine A úlohu riešilo úlohu riešilo 40 l'udí. Dosiahnuté štatistické hodnoty boli: aritmetický priemer 2,76, smerodajná odchýlka 1,43, rozptyl 2,04. V skupine B úlohu riešilo 39 l'udí. Úspešnost' študentov je uvedená v tabul'ke 8. Aritmetický priemer bol 2,3, smerodajná odchýlka 1,83, rozptyl 3,3.
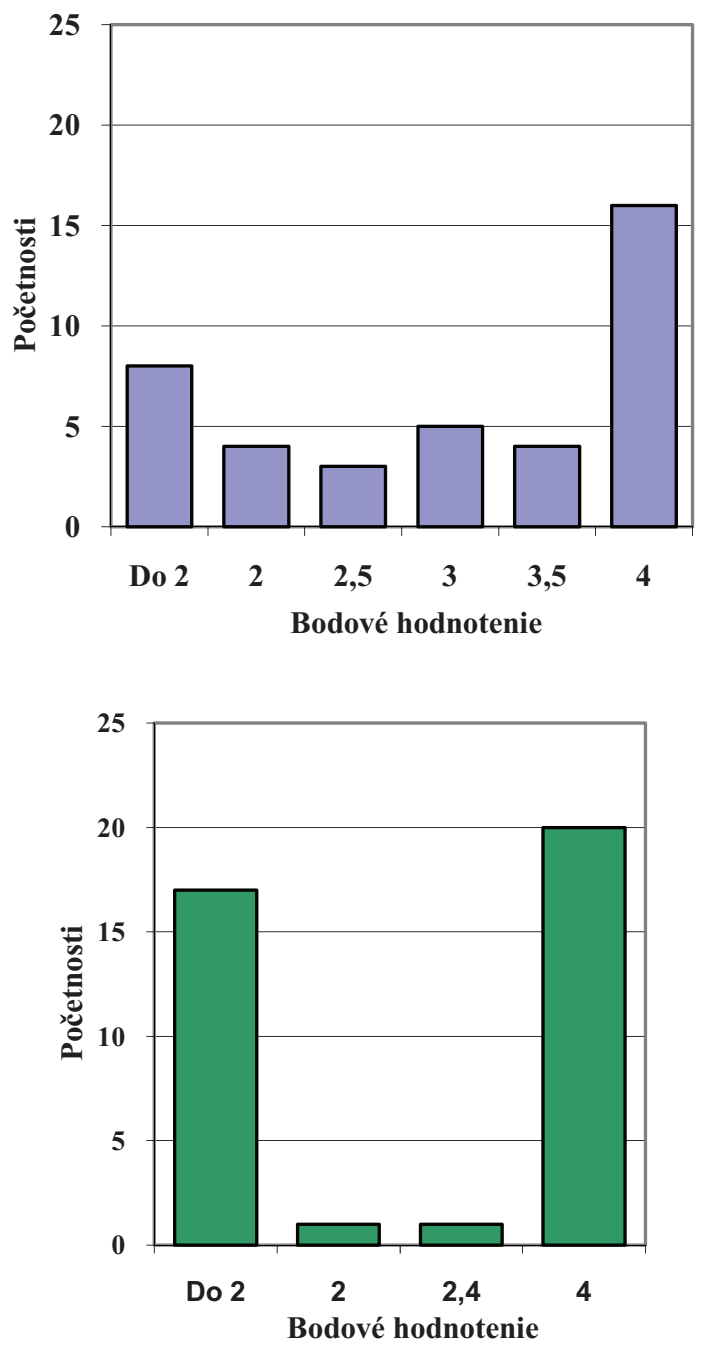

Obr 7: Porovnanie výsledkov úspešnosti $v$ skupine $A$ a $v$ skupine $B$

Testujeme hypotézu pre riešenie diferenciálnych rovníc.

$H_{0}:\left(F_{1}(x)=F_{2}(x)\right)$ proti $H_{1}:\left(F_{1}(x) \neq F_{2}(x)\right)$

Usporiadame $n=79$ hodnôt podla vel'kosti a priradíme im poradie $X_{11}, \ldots X_{1 n_{1}}$ a $X_{21}, \ldots X_{2 n_{2}}$. Určíme štatistiky

$S_{1}=n_{1} n_{2}+\frac{n_{1}\left(n_{1}+1\right)}{2}-T_{1}=734 \mathrm{a}$

$S_{2}=n_{1} n_{2}+\frac{n_{2}\left(n_{2}+1\right)}{2}-T_{2}=826$. pričom

$T_{1}=X_{11}+X_{12}+\ldots+X_{1 n_{1}}=1646 \mathrm{a}$

$T_{2}=X_{21}+X_{22}+\ldots+X_{2 n_{2}}=1514$.

Ked'že $n$ je dostatočne vel'ké, určíme veličinu

$U=\frac{S_{1}-\frac{n_{1} n_{2}}{2}}{\sqrt{\frac{n_{1} n_{2}}{12}\left(n_{1}+n_{2}+1\right)}}=0,45$ 
Kedže platí, že $|U| \geq 2,576, \quad u\left(\frac{\alpha}{2}\right)=2,576$, hypotézu na hladine významnosti 0,01 nezamietame.

\section{Kvantitatívne zhodnotenie výsledkov hypotézy 3}

Pre overenie tejto hypotézy sme si zostavili tabul'ku relatívnych početností úloh s plným bodovým hodnotením (stopercentne zvládnutých úloh) $\mathrm{v}$ jednotlivých skupinách $\mathrm{A}$ a $\mathrm{B}$ pri predchádzajúcej hypotéze 2. Pre interpretáciu situáciu zhodnotíme aj graficky na obrázku 8.

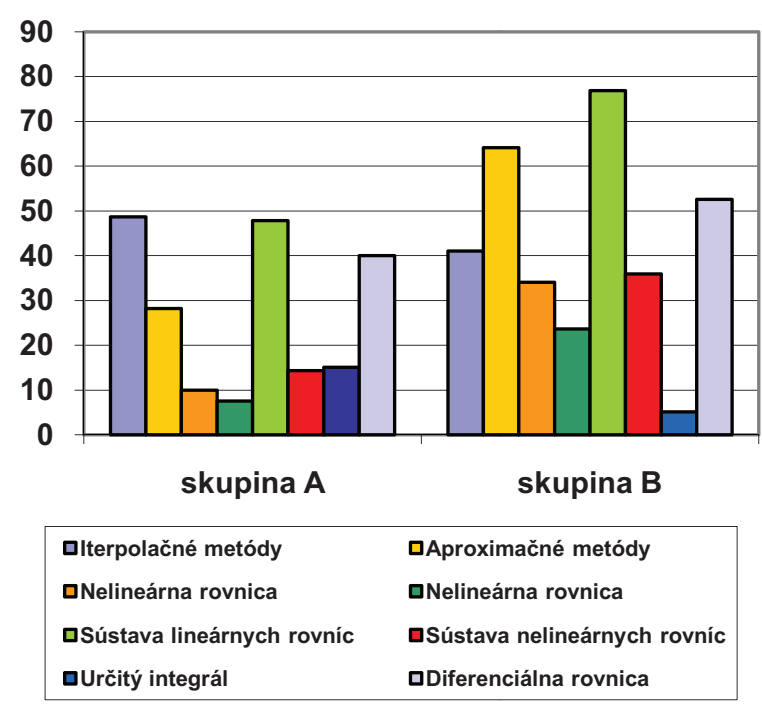

Obr 8: Porovnanie relatívnych početností úplne vyriešených úloh u študentov v skupine A a v skupine B

\section{Kvantitatívne zhodnotenie výsledkov hypotézy 4}

Pre celkové zhodnotenie hypotézy 4 je zostavená tabul'ka 1 percentuálneho podielu iba numerických chýb v skupine A a v skupine B.

Tabul'ka 1: Percentuálny podiel numerických chýb v skupine A a v skupine B

\begin{tabular}{|l|l|l|}
\hline \multicolumn{1}{|c|}{ Úloha na teste } & $\begin{array}{c}\text { Výsledky } \\
\text { v skupine } \\
\text { A (\%) }\end{array}$ & $\begin{array}{l}\text { Výsledky } \\
\text { v skupine } \\
\text { B (\%) }\end{array}$ \\
\hline Interpolačné metódy & 23,07 & 15,38 \\
\hline Aproximačné metódy & 17,95 & 10,26 \\
\hline Nelineárna rovnica 1 & 0 & 0 \\
\hline Nelineárna rovnica 2 & 2,5 & 0 \\
\hline $\begin{array}{l}\text { Sústava lineárnych } \\
\text { rovníc }\end{array}$ & 4,35 & 0 \\
\hline Sústava nelin. rovníc & 7,14 & 0 \\
\hline Určitý integrál & 25 & 7,7 \\
\hline Diferenciálna rovnica & 15 & 0 \\
\hline
\end{tabular}

\section{Záver}

Kvalita výučby týchto metód má vplyv na celkové zvládnutie štúdia na technických fakultách. [5] Ciel'om je predmet maximálne zefetívnit' a získané výsledky zapracovat' do metodiky predmetu Aplikovaná matematika.

Párovým testom bola hypotéza 1 zamietnutá, potvrdila sa štatisticky významná rozdielnost'. Celkovo ju považujeme za potvrdenú.

Splnenie hypotézy 2 je rôzne, závisí od úlohy. Rovnost' výberov bola zamietnutá a zlepšenie nastalo pri aproximáciách, sústavách rovníc, nelineárnych rovniciach. Zhoršenie pri určitom integrále. Pri diferenciálnych rovniciach a interpoláciach sme hypotézu nezamietli.

Pri hypotéze 3 sa vyššie percento úplne vyriešených úloh $\mathrm{v}$ B potvrdilo pri nelineárnych rovniciach, aproximačných metódach, sústavách rovníc. Pri diferenciálnych rovniciach bolo iba mierne vyššie, pri interpolačných metódach nižšie a pri integrálnom počte podstatne nižšie.

$\mathrm{K}$ hypotéze 4: pri algoritmoch riešených na PC sa minimalizovalo množstvo numerických chýb. Častejšie sa potom vyskytovali chyby zlého použitia PC. Študenti ho používali mechanicky a neoverovali správnost' riešenia úloh.

\section{Literatura}

[1] OMACHELOVÁ M. Numerická matematika a nový prístup $\mathrm{k}$ jej výučbe. In: Zborník z 2. medzinárodnej konferencie APLIMAT 2003. Bratislava: STU, 2003. ISBN 80-227-1813-0

[2] TUREK, I. Učitel' a pedagogický výskum. Bratislava: MC, 1998. ISBN 80-8052-013-5

[3] RIEČAN, B et al. Pravdepodobnost' a matematická štatistika. Bratislava: Alfa, 1984. ISBN 63-560-84

[4] HRUBINA, K. et al. Riešené úlohy algoritmami numerických metód. Košice: Informatech, s. r. o., 2000. ISBN 80-88941-16-4 [5] STRAKA, L'. Využívanie ICT pre diagnostiku procesov vo vyučovacom procese vibrodiagnostiky. In: INFOTECH 2007. Olomouc: Votobia, 2007. p. 730-733. ISBN 978-80-7220-301-7.

\section{PaedDr. Jana Boržíková, PhD.}

Katedra matematiky, informatiky a kybernetiky

Fakulta výrobných technológií TUKE so sídlom v Prešove, Bayerova 1

080 01, Prešov, SR

Tel: +421 517723931

E-mail: jana.borzikova@tuke.sk, Www pracoviště: http://web.tuke.sk/fvtpo/ 